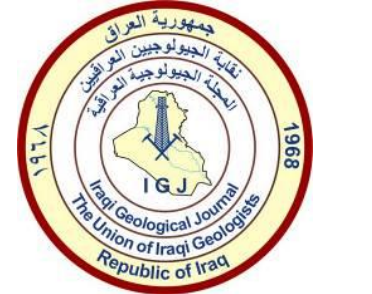

Iraqi Geological Journal

Journal homepage: https://www.igj-iraq.org

\title{
Assessment of Heavy Metal Pollution in Clay Fraction of the Euphrates River Sediments, AlQaim, Haditha Area, Western Desert Iraq
}

\author{
Awaz Rasul ${ }^{1, *}$ and Hikmat Al-Jaleel ${ }^{2}$ \\ Department of Geology, College of Science, University of Salahaddin, Erbil, Iraq \\ Department of Geology, College of Science, University of Salahaddin, Erbil, Iraq \\ Correspondence: awaz.rasul@su.edu.krd
}

\begin{abstract}
Received:

Clay fractions $(<2 \mu \mathrm{m})$ from ten stream sediments were collected from the Euphrates River between AlQaim-Haditha area in the western desert of Iraq. The clay fractions were analyzed

Accepted: for $\mathrm{Cd}, \mathrm{Co}, \mathrm{Cr}, \mathrm{Cu}, \mathrm{Ni}, \mathrm{Pb}, \mathrm{Sr}$, and $\mathrm{Zn}$ using an Atomic Absorption Spectrophotometer. The aim 26 October 2021

Published:

31 January 2022 of this research is to study the extent to which the industrial waste liquids from chemical complex of phosphates pollute stream sediments of Euphrates River. The total metal concentrations in the clay fraction are placed in the following descending order: $\mathrm{Sr}>\mathrm{Zn}>\mathrm{Cr}>$ $\mathrm{Ni}>\mathrm{Co}>\mathrm{Pb}>\mathrm{Cu}>\mathrm{Cd}$. Contamination factor pollution load index, geo-accumulation index, the metal contamination index, and potential ecological risk index were calculated to evaluate the environmental impacts of these heavy metals. The study area was found to be highly contaminated with $\mathrm{Cd}$ and $\mathrm{Ni}$, moderately contaminated with $\mathrm{Co}, \mathrm{Pb}$ and $\mathrm{Sr}$, and uncontaminated with $\mathrm{Cr}, \mathrm{Cu}$ and $\mathrm{Zn} .100 \%$ of $\mathrm{Cd}$ and $93 \%$ of $\mathrm{Sr}$ were concentrated in the extracted part of the clay fraction, suggesting that $\mathrm{Cd}$ is totally derived from the industrial and human activities in the studied area, and $\mathrm{Sr}$ which can be attributed to the carbonates of Euphrates Formation as its source which dominate the geology of the area.
\end{abstract}

Keywords: Euphrates River; Clay fraction; Assessment; Heavy metals; Pollution

\section{Introduction}

With population growth, rapid industrial development, and a lack of pollution control measures, soil trace metal contamination is becoming a global problem at both the private and governmental levels, particularly because soils are an important component of both rural and urban environments (USDA, 2001; Rahman et al., 2012; Tang et al., 2014). Heavy metal accumulation in river sediments exposed to mining and industrial wastes is a regular occurrence in most developing countries (Islam et al., 2015). Heavy metals in the environment are sometimes carried and sourced by sediments (Haiyan et al., 2013). Heavy metals in river sediments enter through different pathways, either from point or non-point sources (Shazili et al., 2006). Grain size distribution plays an important role regarding the content of heavy metals in sediments. Many investigations indicated that when sediments grain size decreases, metal content increases more than those formed of coarser ones (Svetlana et al., 2012). This was attributed to the fact that smaller grains, such as clay fraction sediments, have a larger surface area, which allows heavy metals to be retained in high concentrations (Wang et al., 2006). 
The background level is a measure used to differentiate between the concentration with an anthropogenic influence and the concentrations of the natural occurrence in a given environmental sample (Matschullat et al., 2000; García Sánchez et al., 2010). Heavy metal concentrations in the natural soil background are determined by geological substrates in the Earth's crust and soil formation processes (Alloway, 1990; Kabata - Pendias and Pendias, 2001). Rocks have a large influence on the heavy metal content of soils, with concentrations sometimes exceeding critical values (Salonen and Korkka-Niemi, 2007). The phosphate industry is the major cause of pollution in the area because most of the waste is directly discharged into the river with preliminary treatment. Iraq's major phosphate factory, which is located $20 \mathrm{~km}$ in the western city of AlQaim, was once used to produce fertilizer for agricultural purposes. The waste is liquid or solid and its acidic or basic throw-out from different units. The units that produce the waste material from the factory are fertilizer phosphate unit, phosphoric acid unit and fluoride salt unit. The study area is located between $34^{\circ} 22^{\prime} 12.33^{\prime \prime}-34^{\circ} 08^{\prime} 3.04^{\prime \prime} \mathrm{N}$ and $41^{\circ} 05^{\prime} 46.44^{\prime \prime}-42^{\circ} 22^{\prime} 42.19^{\prime \prime} \mathrm{E}$ including the Euphrates River from AlQaim on the Iraqi Syrian borders to Haditha city for a length of about $160 \mathrm{~km}$ (Fig. 1).

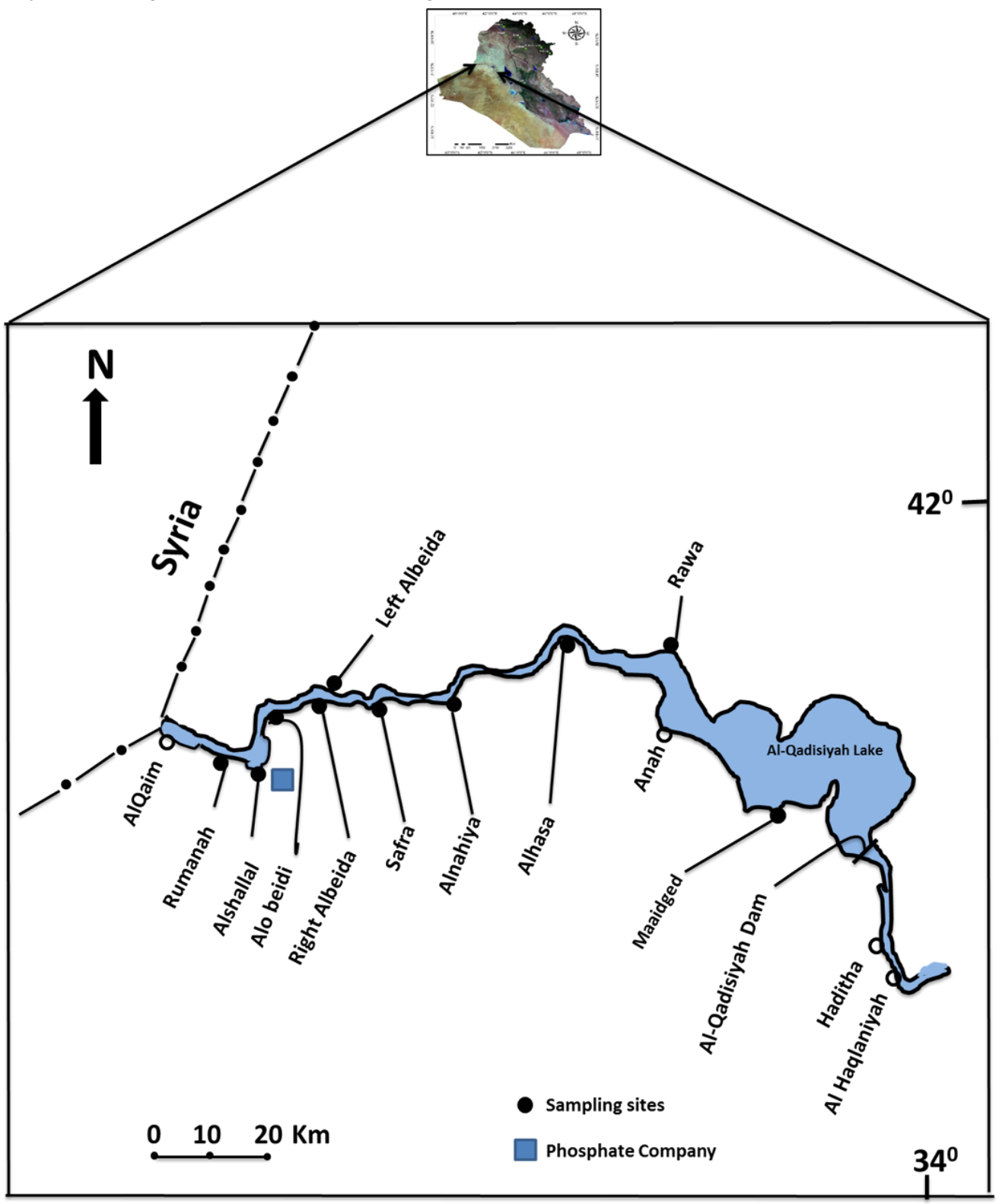

Fig. 1. Location map of the Euphrates River in the study area showing the location of samples and the relevant phosphate chemical complex 
Haditha reservoir is the largest dam along the Iraqi stretch of the Euphrates River with a maximum capacity of $8.2 \mathrm{~km} 3$.The main fluvial units on the Euphrates River in Iraq are terraces and flood plains, which are geomorphological units and forms of the river's course. The Euphrates River defines the boundary between two tectonic zones, Al-Jazira and Western Desert zones, as it enters Iraqi territory from Syria (Fig. 1). The river flows parallel to Anah anticline in $\mathrm{W}-\mathrm{E}$ trend which is the only surface anticline along the course of the river within the Iraqi territory and continues until Haditha town. Although the major part of the Euphrates River's basin is located within the Stable Shelf, but still a lot of indications exist in the basin witnessing Neotectonic activities (Sissakian et al., 2014). According to Sissakian and Al-Jiburi (2007), the exposed formations in the study area are: (1) Anah (Oligocene) which consists of very hard limestone and corals with a thickness of about $40 \mathrm{~m}$; (2) Euphrates Formation (Lower Miocene) which consists of highly fossiliferous limestone, dolostone, marl, with a thickness of about 60-130 m in AlQaim city; (3) Fatha Formation (Middle Miocene) which consists of cyclic deposits of green marl, reddish brown claystone, limestone and gypsum; (4) Nfayil Formation (Middle Miocene) which consists of an alternation of green marl and limestone; and (5) Zahra Formation (Pliocene-Pleistocene) and Quaternary sediments (Pliestocene) which consists of sand, gravel, fine gypsum, and silt with a thickness of about 12-35 m.Previous studies on the area include that of Ali (1972) who determined heavy mineral provinces of recent sediments in the Euphrates and Tigris Basin; Al Jalil (2000) studied the effect of industrial water leakage from the chemical complex of phosphates in Al-Qaim on ground and surface water pollution. Al-Bassam and Al-Mukhtar (2007) who studied the heavy minerals in the $63 \mu \mathrm{m}$ fractions of the Euphrates River sediments that showed enrichment of some heavy metals in the river sediments. Al-Paruany et al., (2017) they studied the distribution of environmental isotopes $\left(\delta^{18} \mathrm{O}, \delta^{2} \mathrm{Hand}{ }^{3} \mathrm{H}\right)$ and hydrochemistry at eight stations in the Euphrates river between Qaim-Falluja. Hussain et al., (2020) twenty-five core samples were selected from eight river bed sediment sites to study the heavy metal contamination of the Euphrates and Shatt al-Arab. The Ta, W, Ni, and Mo were clearly the most contaminated heavy metals in the current investigation. The main aims of this study are to assess of heavy metal pollution in clay fractions and to evaluate the effect of waste material from phosphate chemical complex on the pollution of Euphrates River sediments in the studied area (Fig. 1).

\section{Materials and Methods}

\subsection{Samples Collection}

Ten surface clay samples were collected for the current study along the Euphrates River from the bank of the river between AlQaim on the Iraqi-Syrian border and Haditha towns (Fig. 1). These samples consist of sand, silt and clay. The selected samples were placed in a clean cloth bag and kept in a polyethylene bag. The samples were fully air dried at room temperature and sieved using 80 mesh sieves. The finer fraction was used to separate the clay fraction $(<2 \mu \mathrm{m})$ applying Pipette analysis based on Folk (1974). Fifty grams of each sample were placed into a $500 \mathrm{ml}$ glass cylinder and filled to the mark by distilled water and left one day for the large particles to settle down. The suspended part was decanted into a clean tube for the separation of the $<2 \mu \mathrm{m}$ clay fraction size without adding any chemicals. The separated clay fraction was placed in a polyethylene bag for chemical analysis. The clay samples were analyzed for $\mathrm{Cd}, \mathrm{Pb}, \mathrm{Cu}, \mathrm{Ni}, \mathrm{Co}, \mathrm{Cr}, \mathrm{Zn}$ and $\mathrm{Sr}$ using PYE Unicom SP9 Atomic Absorption Spectrophotometer (AAS) in chemical laboratory at Babylon University. The analysis of these heavy metals was taken place in two stages: 


\subsubsection{Extraction of heavy metals by cold acid}

Include the heavy metals that present in the clay fraction from solution by adsorption and organic complex, that come from the water pollution. This method is available, rapid and not expensive. The procedure of sample preparation is simple, and the analysis consists of only three steps, which can be performed simultaneously: A prepared clay samples $(1.0 \mathrm{~g})$ are placed in a plastic tube $(5 \mathrm{oml})$, and added (20) $\mathrm{ml}$ of cold (0.5) $\mathrm{N}$ hydrochloric acid (Chester and Voutsinou, 1981). The tube closed and shacked in shaker for (16) hours. Finally, put it in a centrifuge (3000) RPM for 20 min to separate the acid from heavy metals, the solution transferred to plastic tubes (20) $\mathrm{ml}$ closed and kept. The heavy metals content from extracted are measured with an Atomic Absorption Spectrophotometer.

\subsubsection{Residual heavy metals}

The procedure of residual extraction includes heavy metals mostly found within the structure of minerals in a silicate matrix of sediments. This extraction is determined by chemical digestion for residual clay fraction after cold extraction. The clay fraction is rinsed with $40 \mathrm{ml}$ of deionized water (DIW) to remove the hydrochloric acid and ionic exchange followed by shaking the tube. The 3000-rpm centrifuge was operated for 30 minutes to separate the water and transfer the deposit to a teflon (P.T.F.E) tube. The deposit was evaporated at $80^{\circ} \mathrm{C}$ to near dryness; followed by adding $6 \mathrm{ml}$ of $\mathrm{HNO}_{3}+\mathrm{HCl}(1: 1)$ acid mixture to be evaporated again $80^{\circ} \mathrm{C}$ to near dryness. An acid mixture of $\mathrm{HF}+\mathrm{Br} 1$ (1:1) is added to the sample and evaporated to near dryness again, followed by adding $1 \mathrm{ml}$ of hydrochloric acid for 10 minutes. The digestion was diluted by $20 \mathrm{ml}$ of deionized water and separated again by centrifuge and finally transferred to a plastic bottle ready to be measured by Atomic Absorption Spectrophotometer.

\subsection{Assessment of Heavy Metals}

The state of heavy metal contamination in the clay fractions of the studied area was evaluated using different quantitative contamination indices. The geochemistry of sediments is an effective indicator to deduce the anthropogenic activity in stream sediments. Among various environmental indices for assessing the degree of anthropogenic induced impact are the contamination factor $(\mathrm{CF})$, pollution load index (PLI), geo-accumulation index $\left(\mathrm{I}_{\text {geo }}\right)$, the metal contamination index (MCI), potential ecological risk index (RI) (Rahman et al., 2012; Jiang, 2013; Adepoju and Adekoya, 2014; Singh et al., 2017; Duncan and Nyarko, 2018; Khudhur et al., 2018; Wojciechowska et al., 2019).

\subsubsection{Contamination Factor (CF)}

$\mathrm{CF}$ is used to express the level of metal contamination in sediment, which is calculated as:

$$
\mathrm{CF}=\mathrm{C}_{\mathrm{m} \text { Sample }} / \mathrm{C}_{\mathrm{m} \text { Background }}
$$

Where $\mathrm{Cm}$ Sample is the amount of a given metal in river sediment and $\mathrm{Cm}$ Background is the value of metal which is equivalent to Upper Continental Crust (UCC) in the studied sediments (Taylor and McLennan, 1985; McLennan, 2001; Rudnick and Gao, 2003; Avumadi et. al., 2019) which was widely used by Harikumar et al., 2009).

\subsubsection{Pollution Load Index (PLI)}

PLI for a specific site was calculated using the approach suggested by Tomlinson et al. (1980). The PLI for various sampling areas were determined as the geometric average for all assessed CF of a sampling site (Afrifa et al., 2013) (Table 2). This parameter is expressed as:

$$
\mathrm{PLI}=\left(\mathrm{CF}_{1} \times \mathrm{CF}_{2} \times \mathrm{CF}_{3} \times \ldots \ldots \ldots \ldots \mathrm{CF}_{\mathrm{n}}\right)^{1 / \mathrm{n}}
$$


Where $\mathrm{n}$ is the number of metals.

\subsubsection{Geo-Accumulation Index}

The $I_{\text {geo }}$ was calculated using the method of Muller (1979). Geo-accumulation index is expressed as follows:

$$
\mathrm{I}_{\mathrm{geo}}=\log _{2}[\mathrm{Cm} /(1.5 \mathrm{Bm})]
$$

Where $\mathrm{Cm}$ is the measured concentration of the metal examined in the sample, and $\mathrm{Bm}$ is the background level of the metal. The 1.5 factor was used to correct possible variations in the background values of a particular metal in the environment.

\subsubsection{The Element Contamination Index and the Metal Contamination Index}

The ECI and the overall metal contamination index (MCI) are expressions of single metal contamination within a sample or total metal contamination for a sample in comparison to the corresponding metal's background values (Singh et al., 2015). They are expressed as:

$$
\begin{aligned}
& \mathrm{ECI}=(\mathrm{Cm}-\mathrm{Bm} / \mathrm{Bm}) \\
& \mathrm{MCI}=\sum(\mathrm{Cm}-\mathrm{Bm} / \mathrm{Bm})^{\mathrm{i}}
\end{aligned}
$$

According to Aikpokpodion et al. (2010), MCI was designed to describe general trace elements contamination.

\subsubsection{Potential Ecological Risk Index}

The Erm evaluates the toxicity of trace elements in sediments and has been extensively applied to assess the comprehensive pollution status in the sediments and environmental effects (Gholizadeh et al., 2019, Liu et al., 2019).). Sediments contaminated by heavy metals can cause serious ecological risks and negatively impact human health due to various forms of interaction where highly toxic heavy metals can enter the food chain. To calculate the $\mathrm{E}_{\mathrm{r}}$ for individual metals, we used the following equation:

$$
\mathrm{E}_{\mathrm{r}}=\mathrm{T}_{\mathrm{r}} * \mathrm{CF}
$$

where $\mathrm{E}_{\mathrm{r}}$ is the potential ecological risk factor/index, Tr represent the toxicity coefficient of each metal whose standard values are: $\mathrm{Hg}=40, \mathrm{Cd}=30, \mathrm{As}=10, \mathrm{Co}=5, \mathrm{Cu}=5, \mathrm{Ni}=5, \mathrm{~Pb}=5, \mathrm{Cr}=2$, and $\mathrm{Zn}=1$ (Hakanson, 1980; Xu et al., 2008). $\mathrm{CF}$ represents the contamination factor $(\mathrm{CF}=\mathrm{C} / \mathrm{B})$, where $\mathrm{Cm}$ is the measured concentration of the pollutant, and $\mathrm{Bm}$ is the level of geological background. To calculate the potential response rate to the toxicity of all the studied heavy metals (RI), we used the following equation:

$$
\mathrm{RI}=\sum^{\mathrm{m}} \mathrm{i}=1 \mathrm{E}_{\mathrm{r}}^{\mathrm{i}}
$$

\section{Results}

Results of heavy metals analysis in clay fraction samples of Euphrates stream sediments are listed in Table 1 and Fig. 2. The results of the Cd content showed that it ranged from 0.27-3.31ppm with an average value of 1.09ppm. The highest concentration of $\mathrm{Cd}$ in Alshallal reached 3.31ppm and Rumanah $1.67 \mathrm{ppm}$. Alshallal area is considered as the area where phosphate chemical complex waste water is discharged in the Euphrates River. The Ni values varied between 115-383 ppm with an average value of 
$180 \mathrm{ppm}$. The highest concentration of Ni in clay fractions at Alhasa is $383 \mathrm{ppm}$ while in Rawa is 212 ppm. Strontium ranged from 88 to $484 \mathrm{ppm}$ with an average of $139 \mathrm{ppm}$, and the highest concentration of $\mathrm{Sr}$ at Rawa is $484 \mathrm{ppm}$ and Alhasa company is 389ppm as shown in Fig. 2. Zinc value varied between 51 to $72 \mathrm{ppm}$ with an average reached to $62 \mathrm{ppm}$.

The highest $\mathrm{Zn}$ concentration in the clay fractions has been found at Rawa and Alnahiya reached $72 \mathrm{ppm}$. Lead concentration ranged between 24 to $66 \mathrm{ppm}$ with an average value reached to $35 \mathrm{ppm}$. The highest content (66) ppm of $\mathrm{Pb}$ was found at Rawa. Copper concentrations ranged from 28 to $47 \mathrm{ppm}$ with an average of $37 \mathrm{ppm}$. Cobalt value varied between 22 to $31 \mathrm{ppm}$ with an average of $26 \mathrm{ppm}$. The chemical analyses did not show a significant variation in the cobalt concentration content, except for a relatively slight increase in the Alnahiya, Alhasa and Rawa. The result of $\mathrm{Cr}$ analysis in clay fractions ranged from 28 to $53 \mathrm{ppm}$ with an average of $39 \mathrm{ppm}$. In general, it has been observed that there is a relative increase in the content of the cadmium, copper, and chromium in the sites located in the downstream, below Alshallal area and the disposal of liquid industrial wastes from the phosphate chemical complex, relative to its concentration when entering the Euphrates River, the Iraqi-Syrian border at Rummana. The $\mathrm{CF}$ value for $\mathrm{Cd}$ was ranged (3 - 36.78) while Ni was (5.75-19.15) especially in the Alshalal which was contaminated by $\mathrm{Cd}$ and Alhasa companied by $\mathrm{Ni}$; other metals range from $\mathrm{Co}$ (2.2-3.1), $\mathrm{Pb}$ (1.2-3.3), $\mathrm{Cu}$ (1.12- 1.88), $\mathrm{Cr}$ (0.8-1.51), $\mathrm{Zn}$ (0.72-1.01) and $\mathrm{Sr}$ (0.25-1.38) (Fig. 3).

The PLI value in the studied clay samples varied from (1.51 to 2.50$)$ with an average of (2.00) (Table 2). The highest PLI value in the studied clay has been found at Rawa (2.50) and AlShallal (2.38). The study area can be divided into three groups according to the level of PLI values for the eight elements calculated by Tomlinson et al. (1980). The first group includes Maaidged, Alobeidi, Safra, and Rumanah where PLI values range from (93.32 to 14.6). The second group includes Alnahiya, Right Albeida (R. Albeida), Left Albeida (L. Albeida), and Alhasa where PLI values varied from (36.6 to 63.18), and the third group includes Rawa (189.8) and Alshallal (130.4) (Fig. 4). The average Igeo value in clay fractions of heavy metals varied from $I_{\text {geo }} \leq 0$ to 2.68 . The highest $I_{\text {geo }}$ average value of trace metals in the studied area has been found in Cd $\mathrm{I}_{\text {geo }} 2.68$ and Ni ( $\mathrm{I}_{\text {geo }} 2.49$ ) (Table 3).

The results shown that the $\mathrm{I}_{\text {geo }}$ of $\mathrm{Zn}, \mathrm{Cu}, \mathrm{Sr}$, and $\mathrm{Cr}$ within $\mathrm{I}_{\text {geo }} \leq 0$, while its lead and cobalt values varied from $0<\mathrm{I}_{\text {geo }}<1$. The study showed that the $\mathrm{I}_{\mathrm{geo}}$ value of nickel is relatively homogeneous within the different locations, while a relative decrease was observed in the $\mathrm{I}_{\text {geo }}$ values of lead in the locations of the Down Stream (Fig. 5). The current study compared the results of the clays analyzes of heavy metals with their average in Upper Continental Crust (UCC) to assess contamination levels of the Euphrates River areas by used Element Contamination (ECI) and the Metal Contamination Index (MCI). The highest Cd-ECI value in the studied clay samples has been found at Alshallal (35.78) and lowest at Alhasa (2.0) with an average of (10.39), while the Ni-ECI value reach to 18.15 in Alhasa and to 4.75 in Rumanah. The results also showed that the values of ECI for the other elements varied from negative values and less than $<5$ (Table 4). As for the MCI values varied from 11.06 to 23.52, except for Alshallal where its values increased to reach 44.32 (Fig. 6).

The assessment of heavy metals showed that the average potential ecological risk indices of $\mathrm{Zn}$ (0.9), $\mathrm{Pb}$ (8.8), $\mathrm{Cu}$ (7.4), $\mathrm{Co}$ (13.1), and $\mathrm{Cr}$ (2.2) in all locations of the study area were lower than $\mathrm{Er}<40$ (Table 5). Cadmium and nickel in the present study considered the main elements causing ecological hazards were $\mathrm{Cd}(\mathrm{Er}=365)$ and $\mathrm{Ni}(\mathrm{Er}=45.0)$. For the $\mathrm{Cd}$ element, there were Alhasa (90) and Rawa (147) have $80 \leq \mathrm{Er}<160$. As that L. Albeida (257), Alnahiya (283) and Maaidged (160) have $160 \leq \mathrm{Er}<320$, while Rumanah (557), Alshallal (1103), Alobide (323), Albeida R. (383) and Safra (343) have $320 \leq \mathrm{Er}$. As for the element nickel, Er in the Rumanah (28.8), Alshallal (34.8), Alobeidi (30.5), Safra (33.5) and Maaidged (32.5) with a content of less than $\mathrm{Er}<40$ (Table 6).

The study area can be divided into three regions according to its content of Potential toxicity response indices for heavy metals (RI) includes Rumanah (613) and Alshallal (1171) with a content of more than $600 \leq \mathrm{RI}$, and the second group includes Alobide (381), Albeida R. (341). Albeida L. (460), 
Safra (406) and Alnahiya (365) with a content between $300 \leq \mathrm{RI}<600$. The third group includes Alhasa (220), Rawa (244) and Maaidged (222) with a content between $150 \leq \mathrm{RI}<300$ (Fig. 7).

Table 1. Concentrations of specific heavy metals in ppm in the extraction and residual clay fractions of the Euphrates River sediments

\begin{tabular}{lcccccccccccccccc}
\hline \multicolumn{1}{c}{ Extraction clay fraction } & \multicolumn{1}{c}{ Residual clay fraction } \\
\hline Stations & $\mathbf{C d}$ & $\mathbf{Z n}$ & $\mathbf{N i}$ & $\mathbf{P b}$ & $\mathbf{C u}$ & $\mathbf{C o}$ & $\mathbf{S r}$ & $\mathbf{C r}$ & $\mathbf{C d}$ & $\mathbf{Z n}$ & $\mathbf{N i}$ & $\mathbf{P b}$ & $\mathbf{C u}$ & $\mathbf{C o}$ & $\mathbf{S r}$ & $\mathbf{C r}$ \\
Rumanah & 1.67 & 16 & 29 & 12 & 6 & 7 & 126 & 2.4 & $<0.01$ & 41 & 86 & 18 & 22 & 16 & 5 & 31 \\
Alshallal & 3.31 & 23 & 41 & 14 & 17 & 7 & 158 & 4.12 & $<0.01$ & 43 & 98 & 24 & 24 & 18 & 19 & 35 \\
Alobeidi & 0.97 & 17 & 31 & 8 & 9 & 5 & 104 & 1 & $<0.01$ & 42 & 91 & 16 & 25 & 17 & 5 & 35 \\
L. Albeida & 0.77 & 18 & 51 & 12 & 13 & 7 & 158 & 2.56 & $<0.01$ & 46 & 148 & 19 & 34 & 20 & 5 & 41 \\
R. Albeida & 1.15 & 23 & 51 & 17 & 11 & 9 & 144 & 3.1 & $<0.01$ & 44 & 131 & 16 & 22 & 16 & 5 & 40 \\
Safra & 1.03 & 16 & 31 & 8 & 9 & 7 & 94 & 1.78 & $<0.01$ & 42 & 103 & 22 & 23 & 17 & 14 & 35 \\
Alnahiya & 0.85 & 25 & 53 & 20 & 11 & 12 & 122 & 1.66 & $<0.01$ & 47 & 131 & 21 & 24 & 19 & 5 & 36 \\
Alhassa & 0.27 & 14 & 80 & 8 & 13 & 7 & 348 & 3.33 & $<0.01$ & 41 & 303 & 19 & 30 & 22 & 41 & 50 \\
Rawa & 0.44 & 33 & 69 & 48 & 15 & 12 & 452 & 0.2 & $<0.01$ & 39 & 143 & 18 & 30 & 18 & 32 & 41 \\
Maaidged & 0.48 & 13 & 29 & 12 & 9 & 9 & 83 & 0.93 & $<0.01$ & 38 & 101 & 18 & 25 & 17 & 5 & 27 \\
Average & 1 & 20 & 47 & 20 & 11 & 8 & 179 & 2 & - & 42 & 134 & 19 & 26 & 18 & 14 & 37
\end{tabular}

B.L. $=$ the data below detected limit $<0.01 \mathrm{ppm} ; \mathrm{L} .=$ Left, R.= Right source: Al-Jaleel (2000)

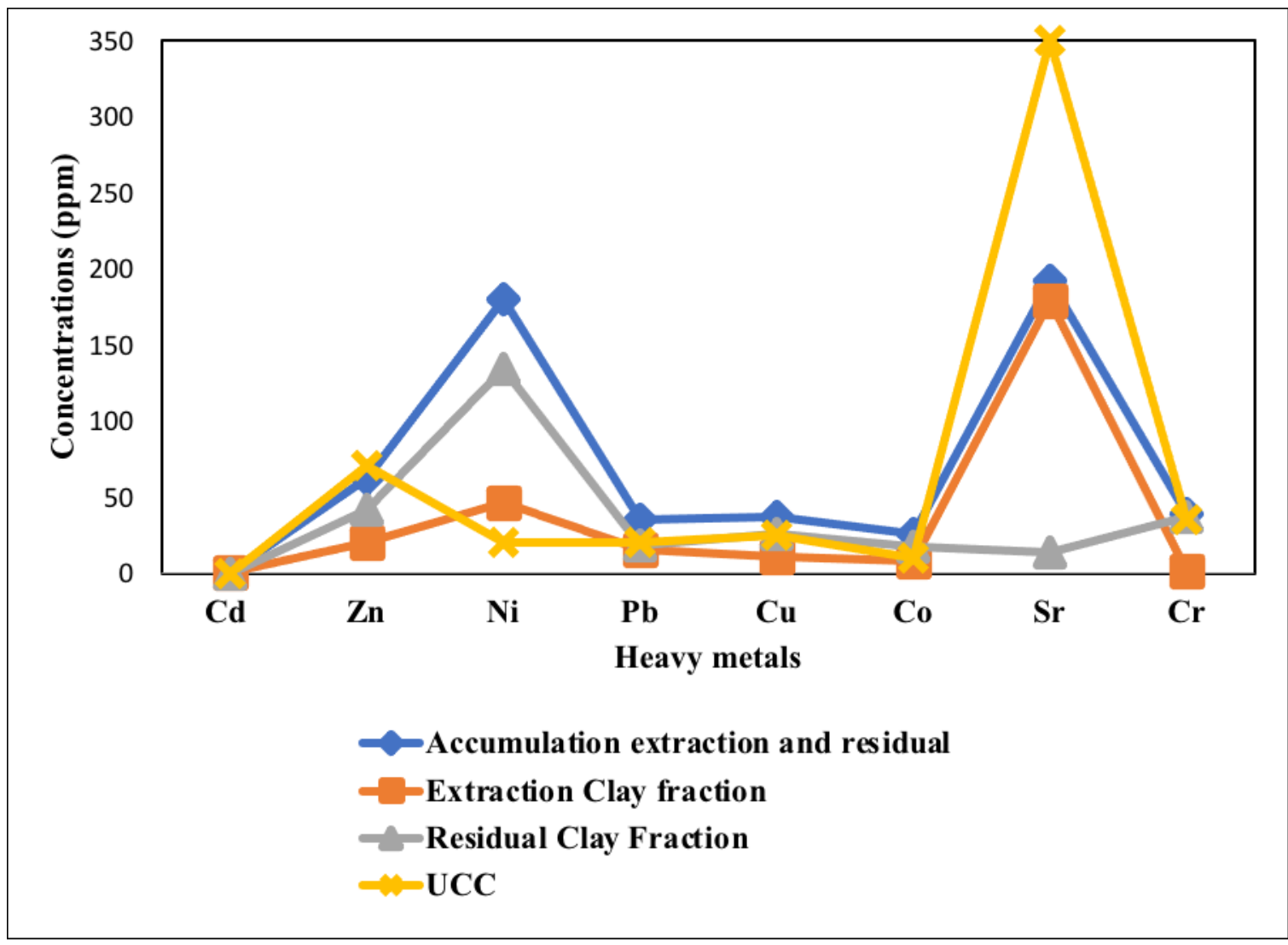

Fig. 2. Average concentrations of heavy metals in extraction, residual, and accumulation of clay fractions with the standards in the study area 
Table 2. CF values and PLI value of heavy metals in the study area and level of contamination (Hakanson, 1980) and pollution (Tomlinson et al., 1980)

\begin{tabular}{|c|c|c|c|c|c|c|c|c|c|}
\hline \multirow[b]{2}{*}{ stations } & \multicolumn{7}{|c|}{ Contamination factors of heavy metal (C F) } & \multirow[b]{2}{*}{$\mathbf{C r}$} & \multirow[b]{2}{*}{ PLI } \\
\hline & Cd & $\mathbf{Z n}$ & $\mathbf{N i}$ & $\mathbf{P b}$ & $\mathbf{C u}$ & Co & $\mathrm{Sr}$ & & \\
\hline Rumanah & 18.56 & 0.8 & 5.75 & 1.5 & 1.12 & 2.3 & 0.37 & 0.94 & 1.81 \\
\hline Alshallal & 36.78 & 0.93 & 6.95 & 1.9 & 1.64 & 2.5 & 0.51 & 1.11 & 2.38 \\
\hline Alobeidi & 10.78 & 0.83 & 6.1 & 1.2 & 1.36 & 2.2 & 0.31 & 1.03 & 1.68 \\
\hline L. Albeida & 8.56 & 0.9 & 9.95 & 1.55 & 1.88 & 2.7 & 0.47 & 1.26 & 2.08 \\
\hline R. Albeida & 12.78 & 0.94 & 9.1 & 1.65 & 1.32 & 2.5 & 0.43 & 1.23 & 2.05 \\
\hline Safra & 11.44 & 0.82 & 6.7 & 1.5 & 1.28 & 2.4 & 0.31 & 1.06 & 1.76 \\
\hline Alnahiya & 9.44 & 1.01 & 9.2 & 2.05 & 1.4 & 3.1 & 0.36 & 1.09 & 2.05 \\
\hline Alhassa & 3 & 0.77 & 19.15 & 1.35 & 1.72 & 2.9 & 1.11 & 1.51 & 2.18 \\
\hline Rawa & 4.89 & 1.01 & 10.6 & 3.3 & 1.8 & 3 & 1.38 & 1.17 & 2.50 \\
\hline Maaidged & 5.33 & 0.72 & 6.5 & 1.5 & 1.36 & 2.6 & 0.25 & 0.8 & 1.51 \\
\hline
\end{tabular}

$\mathrm{CF}<1$ (Low contamination); $1 \leq \mathrm{CF}<3$ (Moderate contamination); $3 \leq \mathrm{CF}<6$ (Considerable contamination); and CF $>6$ (Very high contamination). PLI $<1$ (Perfection) $;=1$ (only baseline levels of pollutants are presented); $>1$ (Deterioration).

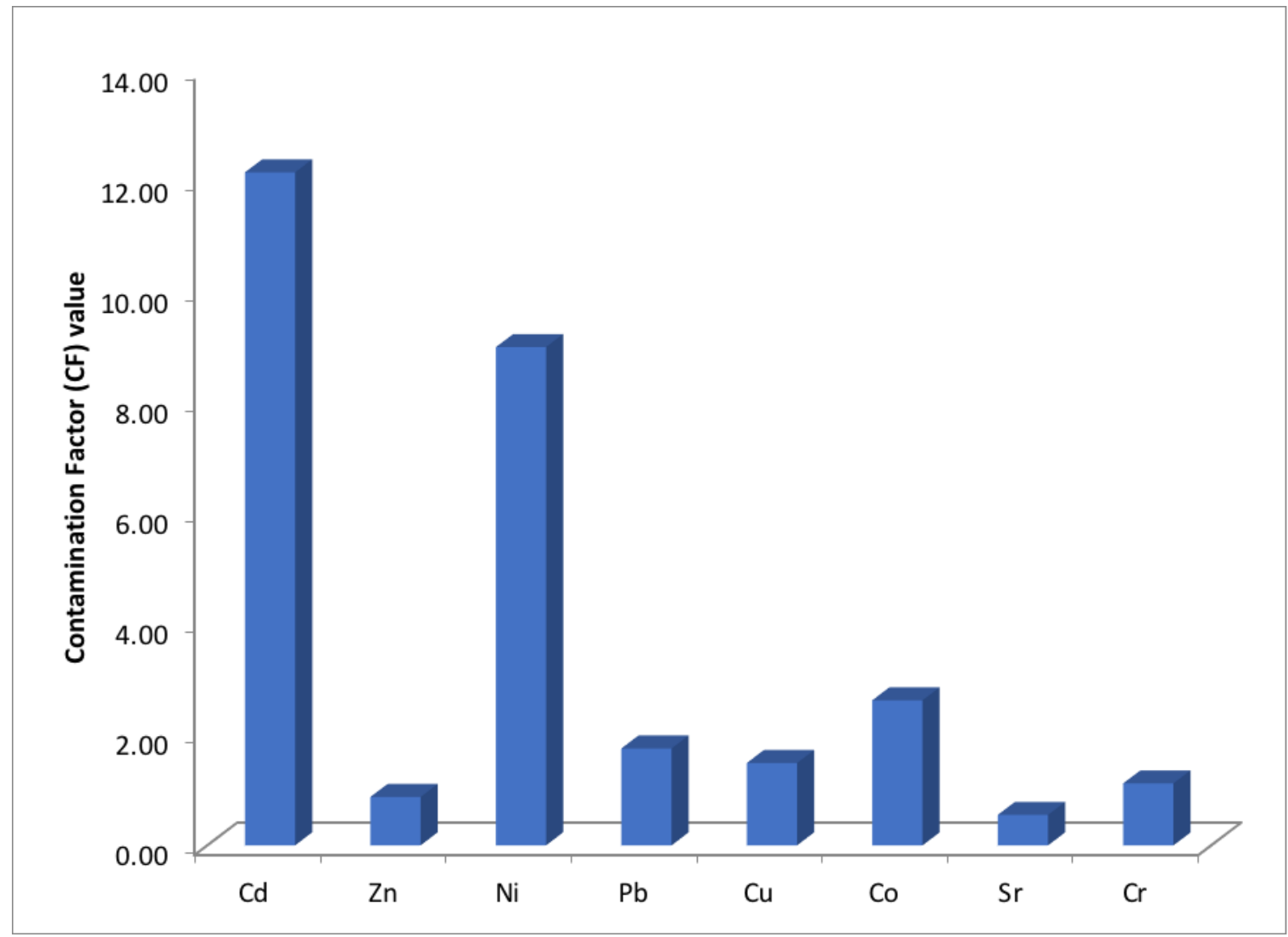

Fig. 3. CF values of heavy metals in the study area 


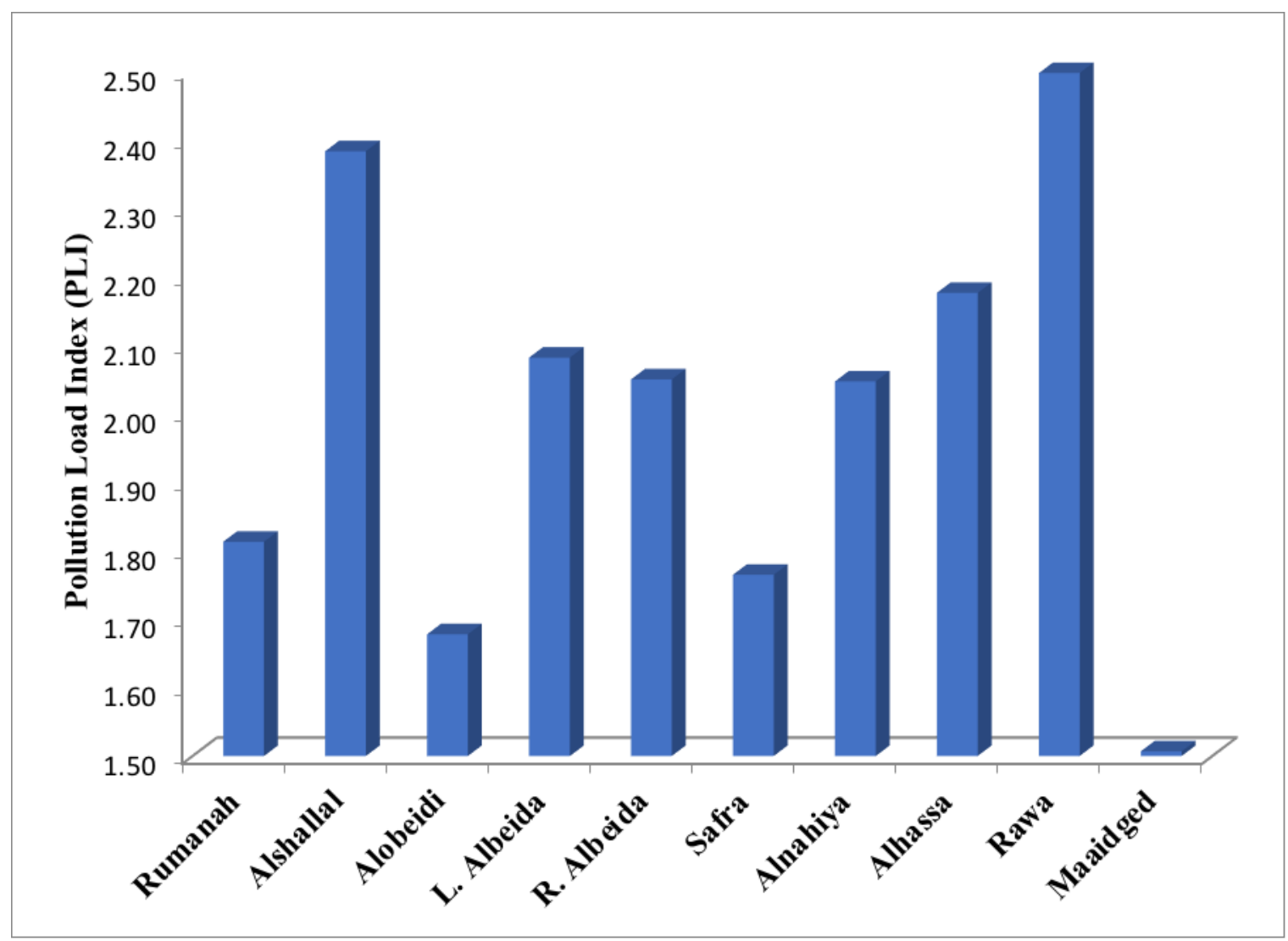

Fig. 4. PLI values of heavy metals in the study area

Table 3. Igeo values of heavy metals in the study area according to Muller's classification (1979)

\begin{tabular}{lrrrrrrrr}
\hline Studied station & $\mathbf{C d}$ & $\mathbf{Z n}$ & $\mathbf{N i}$ & $\mathbf{P b}$ & $\mathbf{C u}$ & $\mathbf{C o}$ & $\mathbf{S r}$ & $\mathbf{C r}$ \\
\hline Rumanah & 3.63 & -0.90 & 1.94 & 0.00 & -0.42 & 0.62 & -2.00 & -0.67 \\
Alshallal & 4.62 & -0.69 & 2.21 & 0.34 & 0.13 & 0.74 & -1.57 & -0.43 \\
Alobeidi & 2.85 & -0.85 & 2.02 & -0.32 & -0.14 & 0.55 & -2.27 & -0.54 \\
L. Albeida & 2.51 & -0.73 & 2.73 & 0.05 & 0.33 & 0.85 & -1.69 & -0.25 \\
R. Albeida & 3.09 & -0.67 & 2.60 & 0.14 & -0.18 & 0.74 & -1.82 & -0.29 \\
Safra & 2.93 & -0.88 & 2.16 & 0.00 & -0.23 & 0.68 & -2.28 & -0.50 \\
Alnahiya & 2.65 & -0.56 & 2.62 & 0.45 & -0.10 & 1.05 & -2.05 & -0.47 \\
Alhassa & 1.00 & -0.95 & 3.67 & -0.15 & 0.20 & 0.95 & -0.43 & 0.01 \\
Rawa & 1.70 & -0.56 & 2.82 & 1.14 & 0.26 & 1.00 & -0.12 & -0.36 \\
Maaidged & 1.83 & -1.06 & 2.12 & 0.00 & -0.14 & 0.79 & -2.58 & -0.91 \\
\hline
\end{tabular}

$\mathrm{I}_{\mathrm{geo}} \leq 0$ (Unpolluted); 0-1 (Unpolluted to moderately polluted); 1-2 (Moderately polluted); $2-3$ (Moderately to strongly polluted); 3-4 (Strongly polluted); 4-5 (Strongly to extensive polluted); and $\mathrm{I}_{\mathrm{geo}}>6$ (Extremely polluted). 


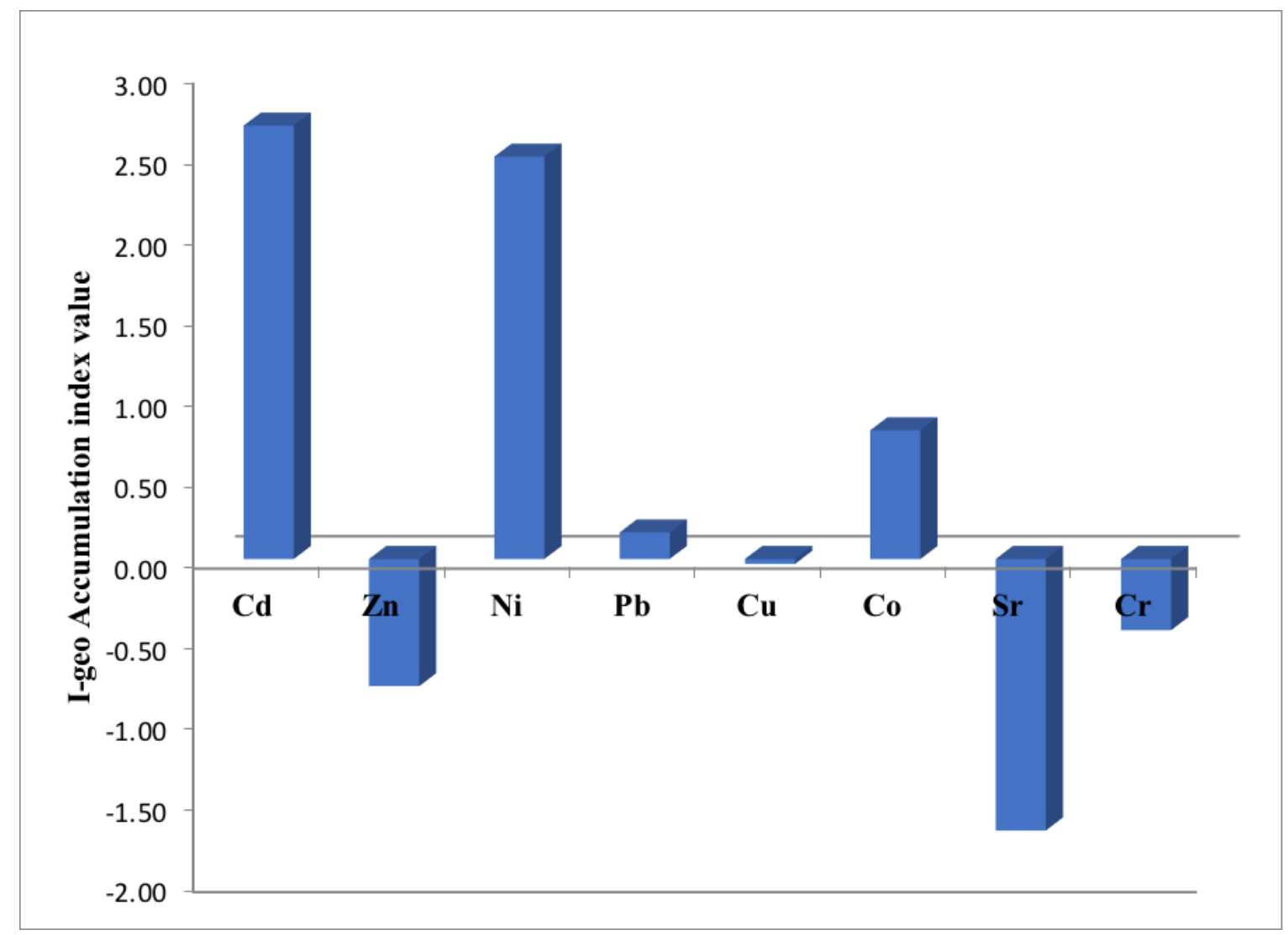

Fig. 5. $\mathrm{I}_{\text {geo }}$ values of heavy metals in the study area

Table 4. ECI and MCI values of heavy metals in the study area and contamination level (Aikpokpodion et al., 2010)

\begin{tabular}{lccccccccc}
\hline \multicolumn{10}{c}{ Element Contamination Index (ECI) } \\
\hline Station & Cd & $\mathbf{Z n}$ & $\mathbf{N i}$ & $\mathbf{P b}$ & $\mathbf{C u}$ & $\mathbf{C o}$ & $\mathbf{S r}$ & $\mathbf{C r}$ & MCI \\
Rumanah & 17.56 & -0.2 & 4.75 & 0.5 & 0.12 & 1.3 & -0.63 & -0.06 & 23.35 \\
Alshallal & 35.78 & -0.07 & 5.95 & 0.9 & 0.64 & 1.5 & -0.49 & 0.11 & 44.32 \\
Alobeidi & 9.78 & -0.17 & 5.1 & 0.2 & 0.36 & 1.2 & -0.69 & 0.03 & 15.81 \\
L. Albeida & 7.56 & -0.1 & 8.95 & 0.55 & 0.88 & 1.7 & -0.53 & 0.26 & 19.26 \\
R. Albeida & 11.78 & -0.06 & 8.1 & 0.65 & 0.32 & 1.5 & -0.57 & 0.23 & 21.95 \\
Safra & 10.44 & -0.18 & 5.7 & 0.5 & 0.28 & 1.4 & -0.69 & 0.06 & 17.51 \\
Alnahiya & 8.44 & 0.01 & 8.2 & 1.05 & 0.4 & 2.1 & -0.64 & 0.09 & 19.66 \\
Alhassa & 2 & -0.23 & 18.15 & 0.35 & 0.72 & 1.9 & 0.11 & 0.51 & 23.52 \\
Rawa & 3.89 & 0.01 & 9.6 & 2.3 & 0.8 & 2 & 0.38 & 0.17 & 19.16 \\
Maaidged & 4.33 & -0.28 & 5.5 & 0.5 & 0.36 & 1.6 & -0.75 & -0.2 & 11.06 \\
Average & 10.39 & -0.19 & 7.5 & 0.7 & 0.44 & 1.55 & -0.56 & 0.07 & 21.56 \\
\hline
\end{tabular}

MCI $<5$ (Very low contamination); 5-10 (Low contamination); 10-25 Medium contamination; 25-50 (High contamination); 50-100 (Very high contamination); and MCI>100 (Extremely high contami 


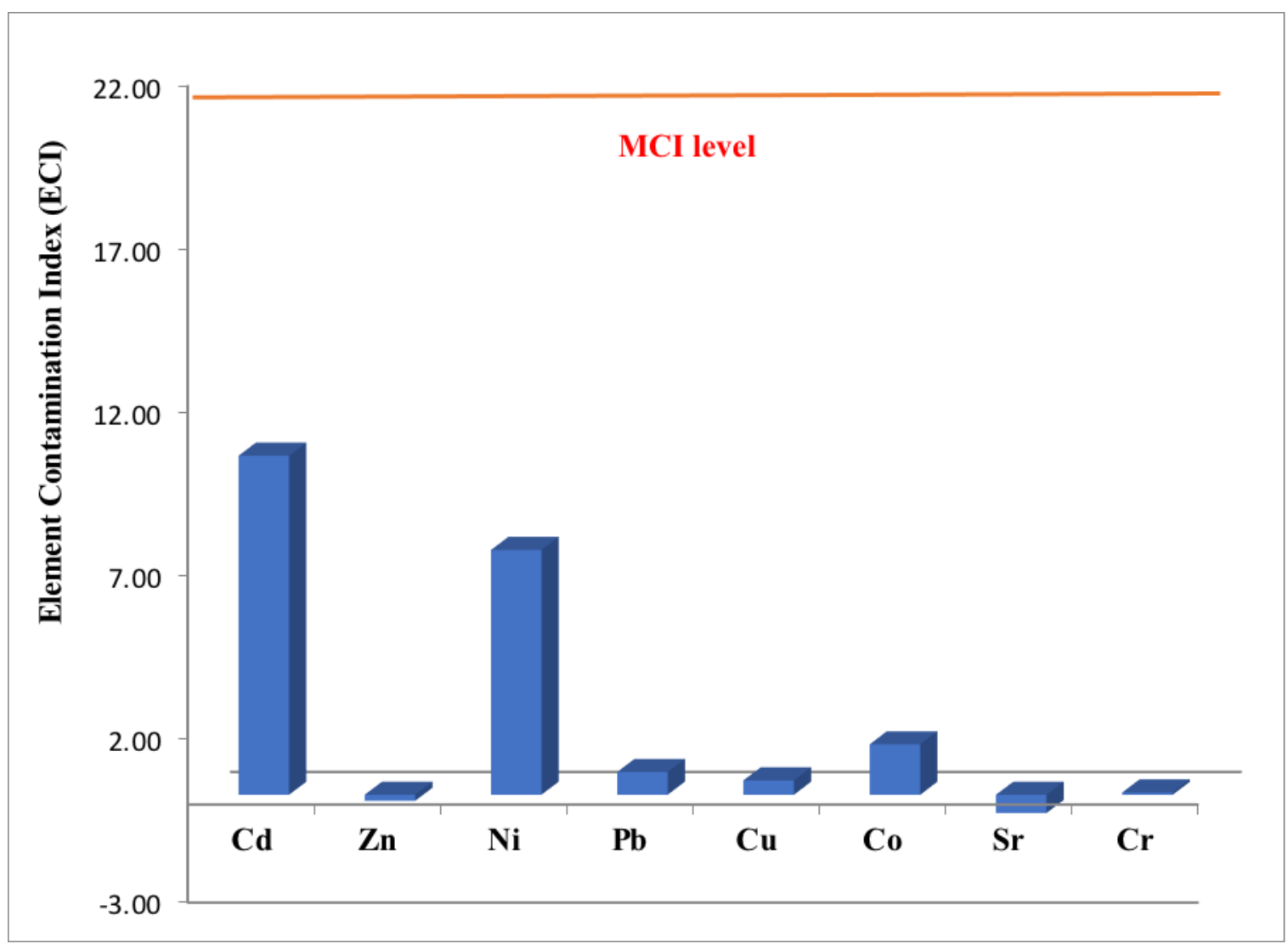

Fig. 6. ECI values and MCI level of heavy metals in the study area

Table 5. Er and RI values of heavy metals in the study area

\begin{tabular}{lccccccccc}
\hline \multicolumn{7}{c}{ Potential ecological risk indices for single heavy metal (Er ) } & & \\
\hline stations & $\mathbf{C d}$ & $\mathbf{Z n}$ & $\mathbf{N i}$ & $\mathbf{P b}$ & $\mathbf{C u}$ & $\mathbf{C o}$ & $\mathbf{C r}$ & $\mathbf{R I}$ \\
Rumanah & 556.7 & 0.8 & 28.8 & 7.5 & 5.6 & 11.5 & 1.9 & 612.8 \\
Alshallal & 1103.3 & 0.9 & 34.8 & 9.5 & 8.2 & 12.5 & 2.2 & 1171.4 \\
Alobeidi & 323.3 & 0.8 & 30.5 & 6 & 6.8 & 11 & 2.1 & 380.5 \\
L. Albeida & 256.7 & 0.9 & 49.8 & 7.8 & 9.4 & 13.5 & 2.5 & 340.6 \\
R. Albeida & 383.3 & 0.9 & 45.5 & 8.3 & 6.6 & 12.5 & 2.5 & 459.6 \\
Safra & 343.3 & 0.8 & 33.5 & 7.5 & 6.4 & 12 & 2.1 & 405.6 \\
Alnahiya & 283.3 & 1 & 46 & 10.3 & 7 & 15.5 & 2.2 & 365.3 \\
Alhassa & 90 & 0.8 & 95.8 & 6.8 & 8.6 & 14.5 & 3 & 219.5 \\
Rawa & 146.7 & 1 & 53 & 16.5 & 9 & 15 & 2.3 & 243.5 \\
Maaidged & 160 & 0.7 & 32.5 & 7.5 & 6.8 & 13 & 1.6 & 222.1 \\
Average & 364.66 & 0.86 & 45.02 & 8.77 & 7.44 & 13.1 & 2.24 & 442.09 \\
\hline
\end{tabular}


Table 6. Categories of Er and RI (Hakanson 1980; Zhu et al., 2008)

\begin{tabular}{lccc}
\hline Er & $\begin{array}{c}\text { Ecological Risk Level of } \\
\text { Single Factor Pollution }\end{array}$ & RI value & $\begin{array}{c}\text { General Level of Potential } \\
\text { Ecological Risk }\end{array}$ \\
\hline $\mathrm{Er}<40$ & low risk & $\mathrm{RI}<150$ & low ecological risk \\
$40 \leq \mathrm{Er}<80$ & moderate risk & $150 \leq \mathrm{RI}<300$ & moderate ecological risk \\
$80 \leq \mathrm{Er}<160$ & considerable risk & $300 \leq \mathrm{RI}<600$ & considerable ecological risk \\
$160 \leq \mathrm{Er}<320$ & high risk & $\mathrm{RI}>600$ & very high ecological risk \\
$\mathrm{Er}>320$ & very high risk & & \\
\hline
\end{tabular}

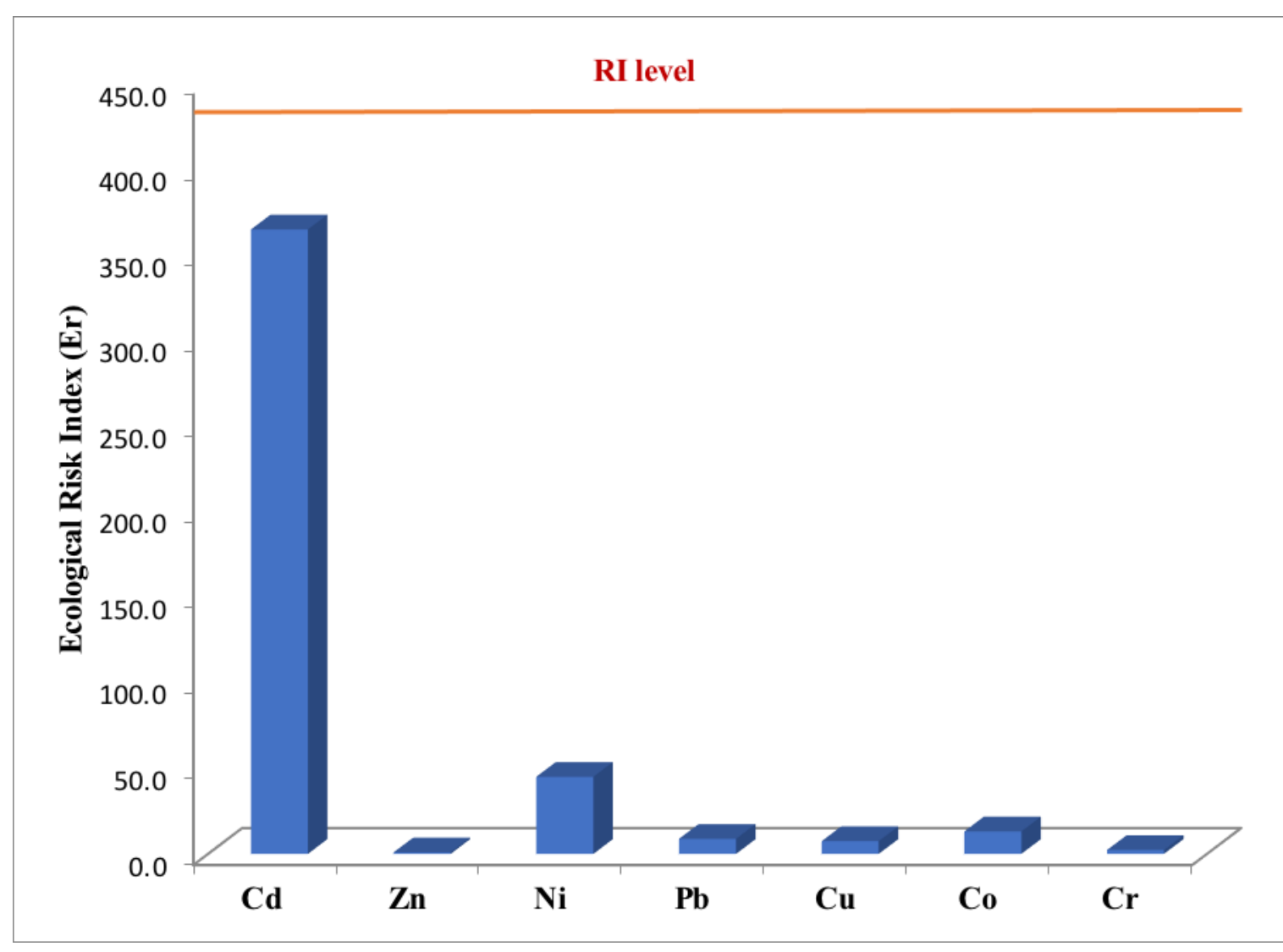

Fig. 7. Er values and RI level of heavy metals in the study area

\section{Discussion}

\subsection{Assessment of Heavy Metals Contamination Indices}

Heavy metals content varies in the environment depending on the geological nature of river crossing areas as well as human activities such as industrial plants, pesticides, agricultural fertilizers, fossil fuel, land construction activities and soil erosion caused by rainfall (Xiang et al., 2002; Chen et al., 2004; Higgins et al., 2007). The accumulations of metal concentrations in the clay fraction are placed in the following descending order: $\mathrm{Sr}>\mathrm{Zn}>\mathrm{Cr}>\mathrm{Ni}>\mathrm{Co}>\mathrm{Pb}>\mathrm{Cu}>\mathrm{Cd}$. The results of $\mathrm{Cd}$ analysis in the present study represent the influence of the waste water disposed from the phosphate chemical complex. Generally, $\mathrm{Cd}$ and other metals occur in waste water at low concentrations until below detection limit of analytical instruments (Al-Jaleel, 2000). These metals tend to accumulate in the clay fraction because it contains high clay minerals that have high adsorption potential in the sedimentation environment. The 
highest concentration of $\mathrm{Cd}$ in Alshallal and Rumanah which is attributed to the urban influence of the city of AlQaim. Drever (1997) showed that Cd has the ability to be adsorbed at the surfaces of clay minerals. Fig. 2 shows that the highest concentration of zinc in Rawa and Alnahiya reached 72 ppm; this was due to human activities and waste water from the phosphate chemical complex (Yan et al., 2018). Also, $\mathrm{Zn}$ is found in minerals like ilmenite and magnetite which are present mainly in the sediments of the Euphrates River; this $\mathrm{Zn}$ can be released to the environment during weathering processes and then deposited in light basic conditions (Benni, 2014; González-Costa et al., 2017). The difference in distribution of $\mathrm{Zn}$ in clay fraction may be due to the effect of organic matter, iron and manganese oxides in the river environment because of high adsorption on clay minerals and organic matter (Steenfelt, 1993; Uddin, 2017). The predominance of montmorillonite over the other clay minerals may be due to the increasing rate of $\mathrm{Ni}$ in these areas (Forstner and Wittman, 1981; Mu'azu et.al., 2018). The burning of fuel and the emission of water pumps used for irrigation also pollute the sediments of the Euphrates River with $\mathrm{Pb}$ (Chester and Voutsinous, 1981; Sekabira et al., 2010). Therefore, their weathering by river can be a source of $\mathrm{Pb}$ in Euphrates River.

The presence of $\mathrm{Cu}$ explains the effect of waste water from the phosphate chemical complex at Alshallal in addition to human activity. Co is transported to the sediments after degradation of its bearing minerals, especially pyroxene, and it tends to be adsorbed on clay minerals, mineral oxides and organic matter (Steenfelt, 1993; Baghernejad et al., 2014; Maciąg, 2019). The Co content indicates the effect of the dense population and dumping of heavy waste, manufacturers and waste water that flow directly to the river and pollutes the sediment of the Euphrates River. The increase in $\mathrm{Sr}$ (484 ppm) content in Rawa is due to the Sr-rich rocks such as limestone and gypsum which are dominant along the Euphrates River in the study area (Ali and Wagreich, 2017). The waste water from the phosphate chemical complex contributes to the increase of the Sr content in the sediment of the Euphrates River, where the concentration in the clay extracts reaches $185 \mathrm{ppm}$ at Al-Shallal area. The waste water from the agriculture land which directly drains to the river also increases the $\mathrm{Sr}$ content in sediments at Albeida which reached 158 and 144 ppm on both sides of the river. Sr have a tendency for ion exchange with the clay rich in calcium because of their similar property (Wissocq et al., 2017). The increasing phosphorous content in the waste water from the phosphate chemical complex can also be considered the determining factor of the increased $\mathrm{Cr}$ content in the clay fraction. Dissolved phosphorous in water is a catalyst for the adoption of $\mathrm{Cr}$ and its concentration in sediments (Ramessur and Ramjeawon, 2002; France et al., 2013).

The results of the chemical analyses of the clay models showed that the content of the elements ( $\mathrm{Zn}$, $\mathrm{Ni}, \mathrm{Pb}, \mathrm{Cu}, \mathrm{Co}$ and $\mathrm{Cr}$ ) included in the current study in the residual fractions is relatively higher than in the extracted part, except for the cadmium, which reached $100 \%$ in the extracted part, and conversely the concentration of the strontium reached to $93 \%$ in the residual fractions. The study showed that the concentration of the nickel, copper, cobalt, and zinc in the acid extracted fractions of the clay minerals is relatively homogeneous, and ranges between (26-32) \%, while its percentage of lead reached $46 \%$, and in chromium, it reached 5.4\% (Table 1).

To assess the contamination levels of the Euphrates River, we compared our observations of heavy metal concentrations in clay fractions with published values for Upper Continental Crust (UCC). Pollution indices can be a helpful tool for assessing sediment contamination and have been extensively used by numerous researchers to gauge sediment pollution (e.g., Jing-Jun et al., 2013; Shaari et al., 2015; Yalcin et al., 2016). The current study showed that heavy metal pollution and their descriptive statistical results can be assessed with respect to UCC. CF values for $\mathrm{Cd}$ and $\mathrm{Ni}$ in clay fractions represent considerable to very high contaminated $(\mathrm{CF}>6)$, especially in Alshalal and Rummanah. Anthropogenic input, such as leaded fuel from automobiles and car batteries, is assumed to be the main source of these elements. The first source of $\mathrm{Cd}$ is the Phosphate chemical complex and added fertilizers to the agricultural soil also supplies a considerable amount of Cd; the Iraqi fertilizers contain Cd as TSP 
(21 ppm), MAP (27 ppm), NP (11 ppm), and NPK (8 ppm) (Al-Qaraqhuli, 2005). Co, Pb, Cu and Cr were moderate contaminated $(1 \leq \mathrm{CF}<3$; $\mathrm{Zn}$ and $\mathrm{Sr}$ in low contaminated $(\mathrm{CF}<1)$ (Table 7). The phosphorite deposit in the study area contains varying amounts of $\mathrm{Cd}$, some of which is transferred to fertilizer products during the manufacturing process (Alloway and Steinnes, 1999; Grant and Sheppard, 2008; Terry, 2014). The accumulation of $\mathrm{Cd}$ in the aquatic environment can be potentially harmful due to biological activities in sediment and health of aquatic environments (Rzetala, 2016). The high levels of $\mathrm{Cd}$ are due to a number of sources, including municipal runoff, atmospheric deposition, and residential and industrial effluents. (Khan, 2017).

The clay fractions of Alhasa are also very highly enriched in $\mathrm{Ni}$ such an average comes from significant human influence (Liu et al., 2005; Zhang et al., 2007). $\mathrm{Co}, \mathrm{Pb}, \mathrm{Cu}$ and $\mathrm{Cr}$ showed moderate contamination especially at Alnahiya and Rawa which have an average value of 2.62, 1.75, 1.49 and 1.12 , respectively. The residual $\mathrm{Zn}(0.87)$ and $\mathrm{Sr}(0.55)$ with $\mathrm{CF}$ averages have low contamination effect which indicates that there was no human influence on the clay fractions by these metals. The PLI is a quick tool for comparison of pollution status in various places. The highest value of PLI has 190 at sampling sites to Rawa and Alshallal, indicating the most contaminated sites (Table 11). The sites with PLI values greater $>3$ are polluted sites and suggest input of an anthropogenic source of pollution due to increased human activities (Mmolawa et al., 2011). However, the lowest PLI value is observed at sampling site is 3.32 indicating decreasing pollution load index trend across the Euphrates River; this represents the dilution and dispersion of metals and random fluctuation from source areas (Chakravarty and Patigiri, 2009).

According to Muller's classification, it is evident that the $\mathrm{I}_{\text {geo }}$ values for $\mathrm{Sr}(-1.68)$ and $\mathrm{Zn}$ $(-0.79)$ falls in class $(0)\left(\mathrm{I}_{\mathrm{geo}} \leq 0\right)$ in all sampling locations, indicating that they are unpolluted by this metal in the clay fractions of Euphrates River; meanwhile $\mathrm{Cd}$ (2.68) and $\mathrm{Ni}(2.49)$ fall in class 4 $\left(\mathrm{I}_{\mathrm{geo}}=3-4\right)$, suggesting moderate to strong pollution. The other metals fall in class $1\left(\mathrm{I}_{\mathrm{geo}}=0-1\right)$ with unpolluted to moderately polluted effects are $\mathrm{Co}(0.8), \mathrm{Pb}(0.16)$ and $\mathrm{Cu}(-0.03)$ (Table 8). This demonstrates that the $I_{\text {geo }}$ values seem to be influenced by the lithology of terrain besides possible anthropogenic contribution of $\mathrm{Cd}$ (industrial), $\mathrm{Cu}$ (irrigation water and phosphate fertilizer plant), and $\mathrm{Co}, \mathrm{Cu}$ and $\mathrm{Cr}$ (Sewage sludge mainly from municipal wastes) (Kabata and Mukherjee, 2007; Dou et al., 2013; Jing, 2014; Issa and Qanbar, 2016). Pb is used as a tracer of motor vehicles, and the combustion of leaded gasoline in cars and trucks can be considered a $\mathrm{Pb}$ pollution source due to atmospheric deposition (Rashed, 2001). The increased CF, PLI and $\mathrm{I}_{\mathrm{geo}}$ were attributed to industrial and vehicle emissions and inflows (Sekabira et al., 2010). The MCI with average of 26.95, suggested a Medium to very high contamination by heavy metals in the ecological system such as plants, soil invertebrates and/or mammalian wildlife (Bortey-Sam et al. 2015); this is especially the case in Alshalal (Table 8).

The result of Er show low to moderate risk by $\mathrm{Ni}(45)$ and considerable to very high risk from $\mathrm{Cd}$ (365), especially in Alshalal and Alnaya areas by $\mathrm{Cd}$ and $\mathrm{Ni}$, respectively. The RI range of 219-1171 and average of 442 suggests a moderate to very high ecological risk of heavy metals by $\mathrm{Cd}$ and $\mathrm{Ni}$ in the ecological system such as industrial, plants, soil invertebrates and/or mammalian wildlife (Bortey-Sam et al., 2015), especially in Al-Shallal area. The results also showed that the existence of a gradient of decreasing RI content from entering the Euphrates River to the Iraqi-Syrian border and into the Maaidged (Table 9). 
Table 7. Range and average of CF and PLI values and grade for elements in the clay fraction of the Euphrates River sediments.

\begin{tabular}{lccc}
\hline & CF and PLI value of River Clay Fractions & \\
\hline Heavy metals & Range & Average & CF and PLI Grade \\
$\mathrm{Cd}$ & $3.00-36.78$ & 12.16 & Considerable to very high contamination \\
$\mathrm{Zn}$ & $0.72-1.01$ & 0.87 & Low contamination \\
$\mathrm{Ni}$ & $5.75-19.15$ & 9 & Considerable to very high contamination \\
$\mathrm{Pb}$ & $1.20-3.30$ & 1.75 & Moderate contamination \\
$\mathrm{Cu}$ & $1.12-1.88$ & 1.49 & Moderate contamination \\
$\mathrm{Co}$ & $2.20-3.1$ & 2.62 & Moderate contamination \\
$\mathrm{Sr}$ & 0.55 & Low contamination \\
$\mathrm{Cr}$ & $0.25-1.38$ & 1.12 & Low to moderate contamination \\
$\mathrm{PLI}$ & $0.80-1.51$ & 54.24 & Deterioration \\
\hline
\end{tabular}

Table 8. Range, average and grades of $I_{g e o}$ and MCI values for elements in the sediments of Euphrates River.

\begin{tabular}{lccc}
\hline & I $_{\mathbf{g e o}}$ and MCI values of River Clay Fractions & \\
\hline Heavy metals & Range & Average & Igeo Grade \\
$\mathrm{Cd}$ & $1.00-4.62$ & 2.68 & Moderately to strongly polluted \\
$\mathrm{Zn}$ & $(-1.06)-(-0.56)$ & -0.79 & Unpolluted \\
$\mathrm{Ni}$ & $1.94-3.67$ & 2.49 & Moderately to strongly polluted \\
$\mathrm{Pb}$ & $(-0.32)-1.14$ & 0.16 & unpolluted to moderately polluted \\
$\mathrm{Cu}$ & $(-0.42)-0.33$ & -0.03 & unpolluted to moderately polluted \\
$\mathrm{Co}$ & $0.55-1.05$ & 0.8 & unpolluted to moderately polluted \\
$\mathrm{Sr}$ & $(-2.58)-(-0.12)$ & -1.68 & Unpolluted \\
$\mathrm{Cr}$ & $(-0.91)-0.01$ & -0.44 & unpolluted to moderately polluted \\
$\mathrm{MCI}$ & $11.06-44.32$ & 21.56 & Medium to very high contamination \\
\hline
\end{tabular}

Table 9. Range and average of Potential Ecological Risk Indices (Er) and Potential Toxicity Response Indices (RI) of heavy metals

\begin{tabular}{lccc}
\hline \multicolumn{4}{c}{ Er value of River Clay Fractions } \\
\hline Heavy metals & Range & Average & Er Level \\
$\mathrm{Cd}$ & $90.0-557.0$ & 365 & Considerable to very high risk \\
$\mathrm{Zn}$ & $0.7-1.0$ & 0.9 & low risk \\
$\mathrm{Ni}$ & $28.8-95.8$ & 45 & low to moderate risk \\
$\mathrm{Pb}$ & $6.0-16.5$ & 8.8 & Low risk \\
$\mathrm{Cu}$ & $5.6-9.4$ & 7.4 & Low risk \\
$\mathrm{Co}$ & $11.0-15.0$ & 13.1 & Low risk \\
$\mathrm{Cr})$ & $1.6-3.0$ & 2.2 & Low risk \\
$\mathrm{RI}$ & $219-1171$ & 442 & moderate to very high ecological risk \\
\hline
\end{tabular}




\section{Conclusions}

Geo-accumulation index, Contamination Factor, Pollution load index and Potential Ecological Risk Index were calculated to evaluate the environmental impacts of key pollutant heavy metals in the clay fraction of the Euphrates River. The study area was found to be highly contaminated with $\mathrm{Cd}$ and $\mathrm{Ni}$, moderately contaminated with $\mathrm{Co}, \mathrm{Pb}$ and $\mathrm{Sr}$, and uncontaminated with $\mathrm{Cr}, \mathrm{Cu}$ and $\mathrm{Zn}$. $100 \%$ of $\mathrm{Cd}$ was found in the extracted part of the clay fraction, thus it may be deduced that $\mathrm{Cd}$ in these clay fractions is derived from industrial activities of the phosphate chemical complex and the human activities in the studied area. In spite of the very low concentrations of heavy metals in the waste water from the phosphate complex at present, their concentration may cumulatively increase in the Euphrates sediments, such an increase was observed in the content of $\mathrm{Cr}, \mathrm{Zn}, \mathrm{Cu}$ and $\mathrm{Cd}$ metals in the clay fractions downstream from AlQaim which may be due to pollution by the waste water from phosphate company complex at that locality.

\section{Acknowledgements}

The authors would like to thank Dr. Yawooz Al-Kettanah for the research support. The authors are very grateful to the reviewers, Editor in Chief Prof. Dr. Salih M. Awadh, the Secretary of Journal Mr. Samir R. Hijab, and the Technical Editors for their great efforts and valuable comments.

\section{References}

Adepoju, M. O., Adekoya, J. A., 2014. Heavy metal distribution and assessment in stream sediments of River Orle, Southwestern Nigeria. Arabian Journal of Geosciences, 7(2),743-756.

Afrifa, C. G., Ofosu, F. G., Bamford, S. A., Wordson, D. A., Atiemo, S. M., Aboh, I. J., \& Adeti, J. P., 2013. Heavy metal contamination in surface soil dust at selected fuel filling stations in Accra, Ghana. American Journal of Scientific and Industrial Research, 4(4), 404-413.

Aikpokpodion, P.E., Lajide, L., Aiyesanmi, A.F. 2010. Heavy metals contamination in fungicide treated cocoa plantations in Cross River State, Nigeria. American-Eurasian Journal Agricultural. \& Environment Science, 8(3), 268-274.

Al-Bassam, K.S., Al-Mukhtar, L., 2007. Heavy minerals in the sediments of the Euphrates River in Iraq, Iraqi Bulletin Geology Mining., 4(1), 29- 41.

Ali, A.J., 1972. Heavy minerals provinces of the recent sediments of the Euphrates, Tigris Basin. Bulletin Geological Society, Iraq, 10, 33- 46.

Ali, A., Wagreich, M., 2017. Geochemistry, environmental and provenance study of the Middle Miocene Leitha limestones (Central Paratethys). Geologica Carpathica, 68, 3, 248-268.

Al-Jaleel, H. S., 2000. The Effect of Industrial Waste Water leakage from the Chemical Complex of Phosphates in Al-Qaim on Ground and Surface Water Pollution, M. Sc. Thesis, College of Science, Baghdad University, 172pp.

Alloway, B.J., 1990. Heavy Metals in Soils; Blackie Academic \& Professional: London, UK.

Alloway, B.J., Steinnes, E., 1999. Anthropogenic additions of cadmium to soils. In M.J. McLaughlin, B.R. Singh (eds), Cadmium in Soils and Plants. Kluwer Academic Publishers, Dordrecht, 97-123pp.

Al-Qaraqhuli, N.A., 2005. Content of nutrient elements (Total, water soluable, and available) in the fertilizers (TSP, MAP, NP, and NPK) produced from Al-Qaim plant, Iraqi. Journal of agricultural sciences, 36(5), $35-41$.

Al-Paruany, K.B., Al-Naseri, S., Al-Ajena AH.F., 2017. Distribution of environmental isotopes in the Euphrates river between Qaim-Falluja, western Iraq. Iraqi Geological Journal.50 (1), 149-156

Avumadi, A., Gnandi, K., Probst, J.L., 2019. Trace element distribution and enrichment in the stream sediments of the lake Togo watersheds (south of Togo). Advances in Ecological and Environmental Research, 1-28.

Baghernejad, M., Javaheri, F., Moosavi, A.A., 2014. Adsorption isotherms of copper and zinc in clay minerals of calcareous soils and their effects on X-ray diffraction. Journal Archives of Agronomy and Soil Science, 61(8), 1061-1077. 
Benni, T.J., 2014. Distribution of some heavy metals in the recent sediments of Al-Nasiriya area, Mesopotamia Plain, south Iraq. Iraqi Bulletin of Geology and Mining 10(1), 73 - 92.

Bortey-Sam, N., Nakayama, S.M.M., Akoto, O., Ikenaka, Y., Baidoo, E., Mizukawa, H., Ishizuka, M., 2015. Ecological risk of heavy metals and a metalloid in agricultural soils in Tarkwa, Ghana. Int. Journal Environment Resource Publication Health, 12, 11448-11465.

Chakravarty, M., Patgiri, A., 2009. Metal Pollution Assessment in sediments of the Dikrong River, N. E. India, Journal of Human Ecology, 27(1), 63-67.

Chen, Z., Saito, Y., Kanai, Y., Wei, T., Li, L., Yao, H., 2004. Low concentration of heavy metals in the Yangtze estuary sediments, China: a diluting setting. Journal Estuar Coast Shelf Sci, 60, 91-100.

Chester, R., Voutsinou, F. G., 1981. The initial assessment of trace metal pollution in coastal sediments. Marine Pollution Bulletin, 12(3), 84-91.

Dou, Y., Li J., Zho, J., Hu, B., Yang, S., 2013. Distribution, enrichment and source of heavy metals in surface sediments of the Eastern Beibu Bay, South China Sea. Marine Pollution Bulletin, 67, 137.

Drever, J.I., 1997. The geochemistry of natural waters-surface and groundwater environments, 3rd edn. Prentice Hall, Upper Saddle River, 436 pp.

Duncan, A.E., Vries, N. Nyarko, K. B., 2018. Assessment of heavy metal pollution in the sediments of the river Pra and its tributaries. Water Air Soil Pollution, 229(8), 272.

Folk, R.L., 1974. Petrology of sedimentary rocks: Austin, TX, Hemphill Press, second edition, 182 pp.

Forstner, U., Wittmann, G. T. W., 1981. Metal pollution in the aquatic environment, Springer- Verlag, Berlin, Heidelberg, 486 pp.

France, M.C., Ong, David Menier, N.A.M., Shazili, B.Y., Kamaruzzaman, 2013. Geochemical characteristics of heavy metals concentration in sediments of Quiberon Bay Waters, South Brittany. Oriental Journal of Chemistry, 29 (1), 39-45.

García Sánchez, A., Alonso Rojo, P., Santos Francés, F., 2010. Distribution and mobility of arsenic in soils of a mining area (Western Spain). Science Total Environment, 408, 4194-4201.

Gholizadeh, A., Taghavi, M., Moslem, A., Neshat, A.A., Lari Najafi, M., Alahabadi, A., Ahmadi, E., Ebrahimi Aval, H., Asour, A.A., Rezaei, H., Gholami, S., Miri, M., 2019. Ecological and health risk assessment of exposure to atmospheric heavy metals. Ecotoxicol Environment Safety, 184, 109622.

González-Costa, J.J., Reigosa, M.J., Matías, J.M., Fernández-Covelo, E., 2017. Analysis of the importance of oxides and clays in $\mathrm{Cd}, \mathrm{Cr}, \mathrm{Cu}, \mathrm{Ni}, \mathrm{Pb}$ and $\mathrm{Zn}$ adsorption and retention with regression. Plos One 12(1): e0168523.

Grant, C.A., Sheppard, S.C., 2008. Fertilizer impacts on cadmium availability in agricultural soils and crops. Human and Ecological Risk Assessment, 14, 210-228.

Haiyan, L., Anbang, S., Mingyi, L., Xiaoran, Z., 2013. Effect of pH, temperature, dissolved oxygen, and flow rate of overlying water on heavy metals release from storm sewer sediments. Journal of Chemistry, 2013, 104316.

Hakanson, L., 1980. An ecological risk index for aquatic pollution control of sediment ecological approach. Water Resources, 14, 975-1000.

Harikumar, P.S., Nasir, U.P MujeebuRahman, M.P., 2009. Distribution of heavy metals in the core sediments of a tropical wetland system. International Journal Environment Science Technology, 6(2), 225-232.

Higgins, S.A., Jaffe, B.E., Fuller, C.C., 2007. Reconstructing sediment age profiles from historical bathymetry change in San Pablo bay, California. Estuar Coast Shelf Sci, 73,165-174.

Hussain, M. L., Al-Jaberi M. H., 2020. Composition the bed sediment contamination of the Southern part of Euphrates River with Shatt Al-Arab, Iraq. Iraqi Geological Journal, 53 (1C), 68-89.

Islam, S., Ahmed, K., Habibullah-Al-Mamun, M., Masunaga, S., 2015. Potential ecological risk of hazardous elements in different land-use urban soils of Bangladesh. Science Total Environment, 512-513, 94-102.

Issa, M. J., Qanbar, A. Sh., 2016. Assessment of heavy metal contamination in Euphrates River sediments from Al-Hindiya Barrage to Al-Nasiria City, South Iraq. Iraqi Journal of Science, 57(1), 184-193.

Jiang, M., Zeng, G., Zhang, C., Ma, X., Chen, M., 2013. Assessment of heavy metal contamination in the surrounding soils and surface sediments in Xiawangang River, Qingshuitang District, Plos One, 8(8). 
Jing, L., 2014. Risk assessment of heavy metals in surface sediments from the Yanghe River, China. International Journal of Environmental Research and Public Health, 11, 12441.

Jing-Jun, L., Ying, L., 2013. Study on heavy metal and ecological risk assessment from Gansu, Ningxia and Inner Mongolia sections of the Yellow, China. Spectroscopy and Spectral Analysis, 33(12), 32-49.

Kabata - Pendias, A., Pendias, H., 2001. Trace elements in soils and plants, 3rd Edition, CRC Press, Boca Raton, London, $413 \mathrm{pp}$.

Kabata-Pendias, A., Mukherjee, A.B., 2007. Trace elements from soil to human. Springer Verlag Berlin Heidelberg, 561.

Khan, M.Z.H., Hasan, M.R., Khan, M., Aktar, S., a Fatema, K., 2017. Distribution of heavy metals in surface sediments of the Bay of Bengal Coast. Journal of Toxicology, 7.

Khudhur, N.S., Khudhur, S.M., Ahmad, I.N., 2018. An assessment of heavy metal soil contamination in a steel factory and the surrounding Area in Erbil City. Jordan Journal of Earth and Environmental Science, 9(1), 1-11.

Liu, S., Pan, G., Zhang, Y., Xu, J., Ma, R., Shen, Z., Dong, S., 2019. Risk assessment of soil heavy metals associated with land use variations in the riparian zones of a typical urban river gradient. Ecotoxicology Environment Safety, 181, 435-444

Liu, W.H., Zhao, J.Z., Ouyang, Z.Y., 2005. Impacts of sewage irrigation on heavy metal distribution and contamination in Beijing, China Environment International, 31, 805-812.

Maciąg, L., Zawadzki, D., Kozub-Budzyń, G.A., Piestrzyński, A., Kotliński, R.A., WróbeR.J., 2019. Mineralogy of Cobalt-Rich Ferromanganese Crusts from the Perth Abyssal Plain (E Indian Ocean). Journal Minerals, 9, $84,1-33$.

Matschullat, J.; Ottenstein, R.; Reimann, C., 2000. Geochemical background, can we calculate it? Environment Geology, 39, 990-1000.

McLennan, S.M., 2001. Relationships between the trace element composition of sedimentary rocks and upper continental crust, Geochemistry Geophysics Geosystems. 2.

Mmolawa, K.B., Likuku, A.S., Gaboutloeloe, G.K, 2011. Assessment of heavy metal pollution in soils along major roadside areas in Botswana. African Journal of Environmental Science and Technology, 5 (3), 186.

Mu'azu, N.D., Bukhari, A., Munef, K., 2018. Effect of montmorillonite content in natural Saudi Arabian clay on its adsorptive performance for single aqueous uptake of $\mathrm{Cu}$ (II) and Ni (II). Journal of king Saud universityscience, 06, 003.

Muller, G., 1979. Heavy metals in the surface's sediment of the RhineChanges seitt. Umschan, 79, 778-783.

Rahman, S.H., Khanam, D., Tanveer, M.A., Islam, M.S., Ahsan, M.A., Akbor, M.A., 2012. Assessment of heavy metal contamination of agricultural soil around Dhaka export processing zone (DEPZ), Bangladesh: Implication of seasonal variation and indices. Applied Science, 2, 584-601.

Ramessur, R. T., Ramjeawon, T., 2002. Determination of lead, chromium and zinc in sediments from an urbanized river in Mauritius. Environment International, 28(4), 315-324.

Rashed, M.N., 2001. Cadmium and lead levels in fish (Tilapia nilotica) tissuesas biological indicator for lake water pollution. Environment Monitoring Assessment, 68, 75-89.

Rudnick, R.L., Gao, S., 2003. Composition of the continental crust. In: The Crust Treatise on Geochemistry (ed. Rudnick R.L.), Elsevier-Pergamon, Oxford.

Rzetala, M.A., 2016. Cadmium contamination of sediments in the water reservoirs in Silesian Upland (southern Poland). Journal of Soils and Sediments, 16, 2458.

Salonen, V., Korkka-Niemi, K., 2007. Influence of parent sediments on the concentration of heavy metals in urban and suburban soils in Turku, Finland. Applied Geochemistry, 22, 906-918.

Sekabira K., Oryem Origa, H., Basamba, T. A., Mutumba, G., Kakudidi, E., 2010. Assessment of heavy metal pollution in the urban stream sediments and its tributaries. International Journal Environment Science Technology, 7(3), 435-446.

Shaari, H., Azmi, S.N.H.M., Sultan, K., Bidai, J., Mohamad, Y, 2015. Spatial distribution of selected heavy metals in surface sediments of the EEZ of the East Coast of Peninsular Malaysia. International Journal of Oceanography, 1 .

Shazili, M. N. A., Yunus, K., Ahmad, A. S., Avdullah, N., Abd Rashid, M. K., 2006. Heavy metal pollution in the Malaysian aquatic environment. Aquatic Ecosystem Health \& Management, 9(2), 137-145. 
Singh, S, Raju, N. J., Nazneen, S., 2015. Environmental risk of heavy metal pollution and contamination sources using multivariate analysis in the soils of Varanasi environs, India. Environmental Monitoring and Assessment, 187(6), 345.

Singh, H., Pandey, R., Singh, S.K., Shukla, D.N., 2017. Assessment of heavy metal contamination in the sediment of the River Ghaghara, a major tributary of the River Ganga in Northern India. Applied Water Science, 7 , 4133-4149.

Sissakian, V.K., Al-Ansari, N. Knutson, S., 2014. Origin of some transversal linear features of NE-SW trend in Iraq, and Their Geological Characters. Natural Science, 6, 996-1011.

Sissakian, V.K., Al-Jiburi, B.M., 2007. Stratigraphy of the Western Desert. Iraqi Bulletin of Geology and Mining, 1, 51-124.

Steenfelt, A., 1993. Comparisons of geochemical patterns obtained from stream sediment, stream organics and till in the Nordkalott project in Fennoscandia. Journal of Geochemical Exploration, 49(1-2), 145-159.

Svetlana, M., Natalia L., Sergey L., 2012. The effect of sediment grain size on heavy metal content. Lakes, Reservoirs and ponds, 6(1), 43-54.

Tang, W., Shan, B., Zhang, H., Zhang, W., Zhao, Y., Ding, Y., ... \& Zhu, X., 2014. Heavy metal contamination in the surface sediments of representative limnetic ecosystems in eastern China. Scientific reports, 4(1), 1-7.

Taylor, S.R., McLennan, S.M., 1985. The continental crust: its composition and evolution. Oxford: Blackwell Scientific publications, $312 \mathrm{pp}$.

Terry, L.R., 2014. Cadmium and phosphorous fertilizers: the issues and the science. International Plant Nutrition Institute, Norcross, GA, USA. SYMPHOS, 2013. 2nd International Symposium on Innovation and Technology in the Phosphate Industry. Procedia Engineering, 83, 52-59.

Tomlinson, D. L., Wilson, J. G., Harris, C. R., \& Jeffrey, D. W. 1980. Problems in the assessment of heavy-metal levels in estuaries and the formation of a pollution index. Helgoländer meeresuntersuchungen, 33(1-4), 566-575.

Uddin, M. K.A., 2017. A review on the adsorption of heavy metals by clay minerals, with special focus on the past decade. Chemical Engineering Journal, 308, 438-462.

USDA (United States Department of Agriculture Natural Resources Conservation Soils Quality Institute), 2001. Urban Technical Note; USDA: Washington, DC, USA, 2.

Varnavas, S.P., 1991. Behaviour of heavy metals in relation to sedimentation processes in a semienclosedindustrialised embayment Patraikos Bay, Greece. Proceedings of 4th International Conference "Environmental Contamination. Barcelona, Spain, 522-524.

Wang, X., Qin, Y., Chen, Y., 2006. Heavy meals in urban roadside soils, part 1: effect of particle size fractions on heavy metals partitioning, Environmental Geology, 50.

Wissocq, A., Beaucaire, C., Latrille, C., 2017. Ca and Sr Sorption on Ca-illite: Experimental Study and Modelling, Earth and Planetary Science. 17, 662-665.

Wojciechowska, E., Nawrot, N., Walkusz-Miotk, J., Matej-Łukowicz, K., Pazdro, K., 2019. Heavy metals in sediments of urban streams: contamination and health risk assessment of influencing factors. Sustainability, 11,563 ;

Xiang, L., Lu, X. X., Higgitt, D.L., Wang, S.M., 2002. Recent lake sedimentation in the Middle and Lower Yangtze basin inferred from Cs-137 and Pb-210 measurements. Journal Asian Earth Science, 21,77.

Xu, Z., N,i S., Tuo, X., Zhang, C., 2008. Calculation of heavy metals toxicity coefficient in the evaluation of potential ecological risk index. Environment Science Technology, 31, 112-115.

Yalcin, F., Nyamsari, D.G., Paksu, E., Yacin, M.G., 2016. Statistical assessment of heavy metal distribution and contamination of beach sands of Antalya-Turkey: An approach to the multivariate analysis technique. Filomat, 30 (4), 945.

Yan, X., Liu, M., Zhong, J., Guo, J., Wu, W., 2018. How human activities affect heavy metal contamination of soil and sediment in a long-term reclaimed area of the Liaohe River Delta, North China. Sustainability, 10, 338.

Zhang, L.P., Ye, X., Feng, H., 2007. Heavy metal contamination in Western Xiamen Bay sediments and its vicinity, China. Marine Pollution Bulletin, 54, 974-982.

Zhu, W., Bian, B., Li, L., 2008. Heavy metal contamination of road deposited sediments in a medium size city of China. Environment Monitoring Assessment, 147, 171-181. 